\title{
The Effect of ICT-based Classwide Peer Tutoring (CWPT) Application and Motivation to Biology Education Student Creativity in ICT Learning
}

\section{Pengaruh Penerapan Classwide Peer Tutoring(CWPT) Berbasis ICT dan Motivasi Terhadap Kreativitas Mahasiswa Pendidikan Biologi dalam Pembelajaran ICT}

\author{
Evita Anggereini $^{1)}$, Retni S. Budiarti ${ }^{2)}$ M.Erick Sanjaya ${ }^{3)}$ \\ ${ }^{1,2,3)}$ Staf Pengajar Prodi Pendidikan Biologi Jurusan PMIPA FKIP Universitas Jambi \\ email: evita_pklh@yahoo.com \\ ${ }^{2}$ FKIP Universitas Jambi
}

\begin{abstract}
The rapid development of ICT, especially in learning, could not be parted from ICT intervention. Many benefits obtained from ICT developments, if this technology is utilized optimally in learning, there will have an impact on improving the quality of learning in particular and the quality of education in general. The lack of student knowledge and motivation for ICT technology can have an impact on students' creativity in using this technology optimally in learning. Peer tutoring can be an alternative solution to this problem. Peers who have more understanding and skill in using existing applications in ICT can be empowered to overcome these problems. Peer Tutoring type Classwide Peer Tutoring (CWPT) will be able to help students who are lacking in knowledge, understanding, skills and creativity. The aim of this study is to find out the influence of the application of ICT-based Classwide Peer Tutoring (CWPT) and Motivation towards the creativity of Biology education students in ICT learning.This research is an experimental study with a $2 \times 2$ factorial design. The independent variable in the form of experimental treatment, namely: Peer Tutoring strategy consisting 2 factors, namely CWPT and conventional type, while for attribute variables namely motivation, also consists of 2 factors, namely: high motivation and low motivation. Both of these independent variables will be examined for their influence on the dependent variable, namely student creativity in ICT learning. The population is 6th semester biology education students and the sample was taken by Total Sampling technique. The data analysis technique uses descriptive data analysis and inferential statistics of 2-ways ANOVA.The results of the study show that 1. There is no effect of the CWPT model on student creativity. 2. There is a motivational influence on student creativity in learning ICT. 3. There is no interaction between the model and the motivation to learn ICT with student creativity. Thus, the role of motivation is very large in influencing student creativity.
\end{abstract}

\section{Keywords: Classwide Peer Tutoring (CWPT) model, motivation, creativity}

\begin{abstract}
Abstrak. Perkembangan ICT yang begitu pesat, dunia pendidikan khususnya dalam pembelajaran juga tidak luput dari intervensi ICT ini. Banyak manfaat yang diperoleh dari perkembangan ICT yang kalau teknologi ini dimanfaatkan secara maksimal dalam pembelajaran maka akan berdampak pada peningkatan kualitas pembelajaran khususnya dan mutu pendidikan umumnya. Kurangnya pengetahuan mahasiswa dan motivasi mahasiswa akan teknologi ICT ini dapat membawa dampak terhadap kreatifitas mahasiswa dalam menggunakan teknologi ini secara maksimal dalam pembelajaran padahal banyak manfaat yang dapat diperoleh dari teknologi ini.Peer Tutoring dapat menjadi alternatif pemecahan masalahnya. Teman sebaya yang memiliki pemahaman yang lebih dan terampil dalam menggunakan aplikasi yang ada dalam teknologi ICT ini dapat diberdayakan untuk mengatasi permasalahan tersebut. Peer Tutoring tipe Classwide Peer Tutoring (CWPT) akan dapat membantu mahasiswa yang rendah pengetahuan, pemahaman, skill dan kreativitasnya. Tujuan pene;itian ini adalah untuk mengetahui pengaruh penerapan Classwide Peer Tutoring (CWPT) berbasis ICT dan Motivasi terhadap kreativitas mahasiswa pendidikan Biologi dalam pembelajaran ICT. Penelitian ini merupakan penelitian eksperimen dengan desain faktorial $2 \times 2$. Variabel bebas berupa perlakuan eksperimen yaitu: strategi Peer Tutoring yang terdiri dari 2 faktor yaitu tipe CWPT dan tipe konvensional, sementara untuk variabel atribut yaitu motivasi juga terdiri dari 2 faktor yaitu: motivasi tinggi dan motivasi rendah. Kedua variabel bebas ini akan diteliti
\end{abstract}


pengaruhnya terhadap variabel terikatnya (variabel dependent) yaitu kreativitas mahasiswa dalam pembelajaran ICT. Populasinya mahasiswa pendidikan biologi semester 6 dan sampelnya diambil dengan teknik Total Sampling. Teknik analisis datanya dengan menggunakan analisis data deskriptif dan statistik inferensial anava 2 arah. Hasil penelitian memperlihatkan bahwa 1. tidak terdapat pengaruh model CWPT terhadap kreativitas mahasiswa. 2. Terdapat pengaruh motivasi terhadap kreativitas mahasiswa dalam belajar ICT. 3. Tidak terdapat interaksi antara model dengan motivasi belajar ICT siswa dengan kreatifitas mahasiswa. Dengan demikian peranan motivasi sangat besar sekali dalam mempengaruhi kreatifitas mahasiswa.

\section{Kata kunci: Model Classwide Peer Tutoring (CWPT), motivasi, kreativitas}

\section{PENDAHULUAN}

Seiring dengan perkembangan ICT yang begitu pesat, dunia pendidikan khususnya dalam pembelajaran juga tidak luput dari intervensi ICT ini. Banyak manfaat yang diperoleh dari perkembangan ICT yang kalau teknologi ini dimanfaatkan secara maksimal dalam pembelajaran maka akan berdampak pada peningkatan kualitas pembelajaran khususnya dan mutu pendidikan umumnya. Kemudahan dalam mengakses informasi yang begitu banyak dan jelas baik itu berupa audio visual akan membantu pemahaman mahasiswa dalam pembelajaran. Demikian juga kemudahan dalam memberikan layanan manajemen pembelajaran lewat aplikasi aplikasi yang dimiliki ICT.

Sehubungan dengan hal tersebut Program Studi Pendidikan Biologi menyediakan mata kuliah ICT dalam pembelajaran biologi sebagai wahana bagi mahasiswa untuk mengeksporasi lebih banyak kemajuan ICT yang dapat diaplikasikan dalam pembelajaran Biologi. Mata kuliah tersebut menuntut mahasiswa agar dapat memberdayakan secara maksimal semua kemajuan ICT untuk diintegrasikan ke dalam pembelajaran biologi. Hal tersebut sangat memerlukan pengetahuan dan motivasi mahasiswa untuk mengeksplorasi lebih banyak penggunaan ICT. Hal lain juga diperlukan kreativitas yang tinggi dalam mencari inovasi-inovasi yang ada dalam ICT untuk diterapkan dalam pembelajaran misalnya dalam penyusunan perangkat pembelajaran yang jelas dan menarik berbasis ICT, pengembangan media pembelajaran Biologi interaktif berbasis ICT, manajemen pengelolaan pembelajaran yang efektif berbasis ICT, pengelolaan kelas berbasis ICT, penelusuran jurnal jurnal penelitian yang berkualitas berbasis ICT, pencarian informasi pengetahuan berbasis ICT dan penelusuran topik tugas akhir mahasiswa yang berbasis ICT.

Kurangnya pengetahuan mahasiswa dan motivasi mahasiswa akan teknologi ICT ini dapat membawa dampak terhadap kreatifitas mahasiswa dalam menggunakan teknologi ini secara maksimal dalam pembelajaran, padahal banyak manfaat yang dapat diperoleh dari teknologi ini. Motivasi penting karena memberikan daya penggerak untuk menciptakan kegairahan kerja seseorang, kerjasama dan kerja yang efektif serta kepuasan (Hasibuan, 2009). Hal ini terlihat dari observasi pada mahasiwa pendidikan Biologi, bahwa banyak kemajuan kemajuan teknologi itu tidak banyak mahasiswa paham dalam menggunakannya dan untuk apa penggunaannya. Hal ini terlihat dalam pembelajaran biologi dan penyelesaian tugas akhir mahasiswa dimana setiap 
mahasiswa yang penelitian berkaitan dengan aplikasi aplikasi yang ada di ICT (web, e learning, on line learning, dan lainnya ) masih membutuhkan orang lain yang bidangnya khusus IT untuk membantunya. Padahal mata kuliah tersebut diadakan untuk memfasilitasi hal tersebut. Minimnya waktu pembelajaran ICT ini menjadi kendala utama dalam mempelajari teknologi tersebut. Penggunaan ICT dalam proses pembelajaran banyak memberikan manfaat positif,(Arsyad 2013) dan bisa mengatasi berbagai permasalahan dalam pembelajaran (Susilana, 2011). Hanya beberapa mahasiswa yang bisa terampil menggunakannya. Minimnya mahasiswa yang kreatif mencari inovasi-inovasi pembelajaran yang berbasis ICT. Hal ini terlihat selama pembelajaran ICT tersebut.

Berdasarkan keadaan tersebut maka Peer Tutoring dapat menjadi alternatif pemecahan masalahnya. Strategi ini juga membantu mahasiswa belajar mempromosikan kegiatan kolaboratifnya (Mc. Leod, 2018), dan meningkatkan sikap dalam belajarnya (Chuang, 2018). Strategi ini bila disertai dengan cergam dapat meningkatkan kualitas pembelajaran (Hidayah,2012). Teman sebaya yang memiliki pemahaman yang lebih dan terampil dalam menggunakan aplikasi yang ada dalam teknologi ICT ini dapat diberdayakan untuk mengatasi permasalahan tersebut. Peer Tutoring tipe Classwide Peer Tutoring (CWPT) akan dapat membantu mahasiswa yang rendah pengetahuan, pemahaman, skill dan kreativitasnya. Peer Tutoring tipe ini melibatkan mahasiswa yang lebih senior yang memiliki pemahaman yang lebih untuk membantu mahasiswa yang belum paham. Peer Tutor ini sebelumnya telah dipersiapkan dan dilatih terlebih dahulu oleh dosennya sesuai dengan tuntutan apa yang diinginkan.

Strategi CWPT banyak memberikan keunggulan seperti bermanfaat dalam keaktifan, fokus, kooperatif, percaya diri, kerjasama, koreksi kesalahan dan penguasaan terhadap materi yang dipelajari (Bowman dan Perrot 2009), dapat memberikan koreksi kesalahan langsung, (Greenwood, 2001), mengaktifkan siswa dalam belajar (Bowman dan Perrot, 2009) dan mdapat meningkatkan kualitas pembelajaran (Munawaroh,2015). Pelaksanaan pembelajarannya dalam hal ini melibatkan manajemen pembelajaran yang integrasi ICT, sehingga kendala waktu, jumlah mahasiswa yang banyak, tidak lagi menjadi hambatan yang berarti (Susilana, 2011). Pembelajaran yang mengintegrasikan ICT dapat menjadi pembelajaran yang lebih menarik (Arsyad, 2013. Pembelajaran dengan ICT dapat mendukung timbulnya kreativitas individu ( Asrori, 2007). Pembelajaran dapat dilakukan dimana dan kapan saja. Interaksi antara tutor, tute dan dosen dapat berlangsung dimana saja dan kapan saja dengan melibatkan teknologi ICT. Oleh sebab itu dilakukanlah penelitian yang berjudul :Pengaruh Penerapan Classwide Peer Tutoring (CWPT) berbasis ICT dan motivasi terhadap kreativitas mahasiswa pendidikan Biologi dalam pembelajaran ICT.

Tujuan penelitian ini untuk mengetahui informasi mengenai pengaruh Penerapan Classwide Peer Tutoring (CWPT) berbasis ICT dan motivasi terhadap kreativitas mahasiswa pendidikan 
Biologi dalam pembelajaran ICT. Secara teoritis, penelitian ini diharapkan dapat memberi manfaat bagi mahasiswa Pendidikan Biologi berupa peningkatan pengetahuan akan ICT dan mahasiswa terampil mengaplikasikan aplikasi, software, produk digital yang berbasis ICT ke dalam pembelajaran Biologi dan diharapkan ini dapat menjadi bekal mahasiswa sebagai calon guru untuk lebih kreatif lagi mencari sesuatu yang baru dalam ICT dan mengoperasikannya dalam pembelajaran biologi di sekolah nantinya untuk peningkatan kualitas pembelajaran.

\section{METODE PENELITIAN}

Penelitian ini merupakan jenis penelitian eksperimen. Desain penelitian eksperimen yang dipakai adalah desain faktorial 2x2.Masing-masing variabel perlakuan dalam penelitian ini dibagi 2: strategi Class Wide Peer Tutoring CWPT dan strategi konvensional. Demikian juga untuk variabel atribut dibagi lagi menjadi 2 yaitu siswa dengan motivasi tinggi dan motivasi rendah. Desainnya dapat dilihat sebagai berikut:

Tabel 1. Desain Eksperimen Faktorial 2 x 2

\begin{tabular}{|l|c|c|}
\hline $\begin{array}{c}\text { Variabel atribut } \\
\text { Motivasi (B) }\end{array}$ & \multicolumn{2}{|c|}{$\begin{array}{c}\text { Variabel Perlakuan } \\
\text { Strategi Peer Tutoring(A) }\end{array}$} \\
\cline { 2 - 3 } & Class Wide Peer Tutoring CWPT (A1) & $\begin{array}{c}\text { Konvensional } \\
\text { (A2) }\end{array}$ \\
\hline Tinggi (B1) & A1B1 & A2B1 \\
\hline Rendah (B2) & A1B2 & A2B2 \\
\hline
\end{tabular}

Keterangan :

A1 = Kelompok siswa yang memperoleh strategi Class Wide Peer Tutoring CWPT.

A2 = Kelompok siswa yang memperoleh strategi konvensional.

B1 = Kelompok siswa yang memiliki motivasi belajar tinggi.

B2 = Kelompok siswa yang memiliki motivasi belajar rendah.

Populasi penelitian ini adalah mahasiswa pendidikan Biologi semester 6 yang mengambil mata kuliah ICT dalam pembelajaran Biologi. Seluruh siswa dijadikan sampel dalam penelitian ini (total sampling). Penelitian ini dilakukan di FKIP universitas Jambi khususnya pada Program Studi Pendidikan Biologi dan dimulai awal Maret sampai September 2018. Instrumen yang digunakan adalah angket untuk mengumpulkan data motivasi mahasiswa dan data kreativitas mahasiswa.

Tekhnik analisis data yang digunakan dalam penelitian ini adalah analisis data deskriptif dan analisis data inferensial. Analisis data deskriptif berguna untuk mengetahui kebermaknaan interaksi antara variabel-variabel tersebut dengan menghitung distribusi frekuensi, rata-rata, simpangan baku dan selanjutnya dituangkan dalam bentuk histogram. Analisis data inferensial berguna untuk menguji hipotesis penelitian. Sebelum menguji hipotesis terlebih dahulu harus diketahui dulu normalitas dan homogenitas dari data tersebut. Untuk uji hipotesis digunakan analisis varians (ANAVA) dua jalur dengan taraf signifikansi $5 \%(\alpha=0.05)$. Disain faktorial dengan dua faktor eksperimen dapat dilakukan analisis statistik ANAVA. Hasil uji tersebut berupa $\mathrm{F}$ hitung selanjutnya dibandingkan dengan $\mathrm{F}$ tabelpada setiap faktor perlakuan (A dan $\mathrm{B}$ ) serta interaksi antar faktor (A x B). 


\section{HASIL DAN PEMBAHASAN}

\subsection{Analisis Deskriptif}

Deskripsi data hasil penelitian yang meliputi nilai minimum, maksimum, jumlah, rata rata, standar deviasi dan variansi dapat dilihat pada tabel di bawah ini. Data motivasi yang diperoleh dari angket motivasi yang disebarkan ke mahasiswa sebelum perlakuan penerapan model CWPT. Data kreativitas diperoleh melalui angket yang diberikan kepada mahasiswa setelah perlakuan penelitian. Berdasarkan data yang diperoleh maka dilakukan pengolahan data secara statistik deskriptif terlebih dahulu. Hasilnya dapat dilihat pada tabel 2.

Tabel 2. Analisis deskriptif data kreativitas mahasiswa yang mendapatkan model CWPT dan konvensional dengan melibatkan variabel motivasi tinggi dan motivasi rendah.

\begin{tabular}{|l|l|c|c|c|}
\hline \multicolumn{5}{|c|}{ Descriptive Statistics } \\
\hline \multicolumn{5}{|c|}{ Dependent Variable: Kreativitas } \\
\hline \multirow{4}{*}{ CWPT } & Motivasi & Mean & Std. Deviation & $\mathrm{N}$ \\
\cline { 2 - 6 } & Tinggi & 63.500 & 6.091 & 6 \\
\cline { 2 - 5 } & Rendah & 53.500 & 3.017 & 6 \\
\cline { 2 - 5 } & Total & 58.500 & 6.948 & 12 \\
\hline \multirow{3}{*}{ Konvensional } & Tinggi & 64.000 & 3.742 & 4 \\
\cline { 2 - 5 } & Rendah & 51.250 & 4.646 & 4 \\
\cline { 2 - 5 } & Total & 57.625 & 7.855 & 8 \\
\cline { 2 - 5 } & Tinggi & 63.700 & 5.034 & 10 \\
\cline { 2 - 5 } & Rendah & 52.600 & 3.688 & 10 \\
\cline { 2 - 5 } & Total & 58.150 & 7.132 & 20 \\
\hline
\end{tabular}

Berdasarkan tabel di atas memperlihatkan bahwa pembelajaran ICT dengan model CWPT bagi mahasiswa yang memiliki motivasi tinggi memiliki skor rata-rata kreativitas 63.5 sedangkan mahasiswa yang motivasinya rendah dengan model yang sama memiliki skor kreativitas 53. Secara deskriptif skor mahasiswa yang mendapat model CWPT bagi mahasiswa yang memiliki motivasi tinggi, kreativitasnya lebih tinggi dari kreativitas mahasiswa yang memiliki motivasi rendah. Demikian pula untuk pembelajaran konvensional (non CWPT) mahasiswa yang memiliki motivasi tinggi kreatifitasnya lebih tinggi pula dari kreatifitas mahasiswa yang memiliki motivasi yang rendah. Tetapi ketika dibandingkan kreativitas mahasiswa yang mendapat model CWPT dan konvensional untuk mahasiswa yang memiliki motivasi tinggi dan rendah tidak jauh berbeda.

Rata rata skor kreativitas mahasiswa yang tidak berbeda antara mahasiswa yang mendapat model CWPT dan model tutorial konvesional salah satu alternatifnya dapat disebabkan mekanisme pembelajaran tutorialnya. Tidak berbedanya hasil belajar tersebut dapat disebabkan oleh lingkungan belajar untuk kelas yang diberi CWPT belum optimal untuk mendukung sepenuhnya keefektifan model tersebut. Seperti yang dikemukakan Richardson, Mishra (2018), bahwa lingkungan belajar dapat mempengaruhi mendukung kreatifitas. Penyebab lain mahasiswa belum semuanya berpartisipasi aktif karena keterbatasan waktu, padahal partisipasi kreatif dari mahasiswa ikut mendukung dinamika kelas sehingga harapan terlaksananya CWPT dapat terwujud dengan segala keunggulannya. Dosen (guru) berperanan sekali menghidupkan suasana kelas,sebab guru 
yang kreatif dapat memunculkan karakteristik siswa yang kreatif pula.(Clapp, E.P, 2019). Kreatifitas berkorelasi positif dengan pembelajaran (Ronald, A. Karwowski, 2018).

\subsection{Uji Normalitas}

Sebelum dilakukan pengujian hipotesis terlebih dahulu data diuji normalitas dan homogenitasnya sebagai prasarat untuk uji hipotesis. Hasil uji normalitas memperlihatkan bahwa data kreativitas berdistribusi normal. Hal ini ditunjukkan dengan nilai Sig $0.393>0.05$ untuk kelompok mahasiswa yang memiliki motivasi tinggi dan nilai Sig $0.350>0.05$ untuk kelompok mahasiswa yang memiliki motivasi rendah, Jadi secara keseluruhan data berdistribusi normal. Dengan demikian prasarat analisis untuk uji hipotesis dapat dipenuhi.

\begin{tabular}{|c|c|c|c|c|c|c|c|}
\hline \multicolumn{8}{|c|}{ bel 3. Hasil Uji Normali } \\
\hline & \multirow[b]{2}{*}{ Motivasi } & \multicolumn{3}{|c|}{ Kolmogorov-Smirnova } & \multicolumn{3}{|c|}{ Shapiro-Wilk } \\
\hline & & Statistic & $\mathrm{df}$ & Sig. & Statistic & df & Sig. \\
\hline \multirow[t]{2}{*}{ Kreativitas } & Tinggi & .169 & 10 & $.200^{*}$ & .924 & 10 & .393 \\
\hline & Rendah & 148 & 10 & $200^{*}$ & 0 & 10 & 350 \\
\hline
\end{tabular}

Berdasarkan hasil uji normalitas data kreativitas mahasiswa yang memiliki motivasi tinggi dan motivasi rendah terlihat bahwa nilai Sig > 0.05. maka dapat disimpulkan bahwa kelompok sampel berdistribusi normal, baik itu dengan menggunakan uji Kolmogorov-Sminorv Sig 0.200> 0.05 maupun Shapiro-Wilk dengan nilai Sig 0.393 dan 0.350>0.05.

\subsection{Uji Homogenitas}

Hasil uji homogenitas diperoleh nilai Sig $0.722>0.05$ sehingga datadapat dikatakan homogen.

Tabel 4. Uji Anova data penelitian

\begin{tabular}{|l|l|r|r|r|c|c|}
\hline \multicolumn{2}{|c|}{} & Sum of Squares & df & Mean Square & F & Sig. \\
\hline \multirow{3}{*}{ Model } & Between Groups & 3.800 & 16 & .238 & .713 & .722 \\
\cline { 2 - 8 } & Within Groups & 1.000 & 3 & .333 & & \\
\cline { 2 - 8 } & Total & 4.800 & 19 & & & \\
\hline \multirow{3}{*}{ Motivasi } & Between Groups & 5.000 & 16 & .313 &. & \\
\cline { 2 - 8 } & Within Groups & .000 & 3 & .000 & & \\
\cline { 2 - 8 } & Total & 5.000 & 19 & & & \\
\hline
\end{tabular}

\section{Uji Hipotesis}

Dalam penelitian ini digunakan dua factor yaitu faktor model dan faktor motivasi. Faktor model terdiri dari model CWPT dan model konvensional. Faktor motivasi terdiri dari motivasi tinggi dan rendah. Setiap faktor ini diamati kreativitas mahasiswanya.

Pada model tutorial CWPT mahasiswa dibuat kelompok kelompok pembelajaran. Satu kelompok terdiri dari 5-6 orang, demikian juga halnya pembelajaran dengan model tutorial konvensional. Bedanya pada pembelajaran dengan model CWPT setiap anggota kelompok harus memahami dulu materi ICT yang diberikan. Setiap anggota kelompok model CWPT ini nantinya akan menjadi tutor bagi kelompok kelompok yang lain. Berbeda halnya dengan tutorial konvensional. Hanya satu orang yang mewakili untuk bertindak sebagai tutor bagi kelompok lain. 
Satu orang yang mewakili itu dari setiap kelompok merupakan mahasiswa yang paling paham dan menguasai materi ICT yang akan dipelajari dan dipahami. Mahasiswa ini akan menjadi tutor secara klasikal bagi semua kelompok.

Tabel 5. Levene's Test of Equality of Error Variances

\begin{tabular}{|l|r|r|r|}
\hline F & df1 & df2 & Sig. \\
\hline \multicolumn{1}{|c|}{1.868} & 3 & 16 & .176 \\
\hline $\begin{array}{l}\text { Tests the null hypothesis that the error variance of the dependent } \\
\text { variable is equal across groups. }\end{array}$ \\
a. Design: Intercept + Model + Motivasi + Model * Motivasi \\
\hline
\end{tabular}

Tabel 6. Uji efek perlakuan Model dan motivasi terhadap kreatifitas mahasiswa.

\begin{tabular}{|l|r|r|r|r|r|}
\hline Source & $\begin{array}{c}\text { Type III Sum of } \\
\text { Squares }\end{array}$ & df & Mean Square & \multicolumn{1}{c|}{ F } & \multicolumn{1}{c|}{ Sig. } \\
\hline Corrected Model & $628.800^{\mathrm{a}}$ & 3 & 209.600 & 9.929 & .001 \\
\hline Intercept & 64728.075 & 1 & 64728.075 & 3066.319 & .000 \\
\hline Model & 3.675 & 1 & 3.675 & .174 & .682 \\
\hline Motivasi & 621.075 & 1 & 621.075 & 29.422 & .000 \\
\hline Model * Motivasi & 9.075 & 1 & 9.075 & .430 & .521 \\
\hline Error & 337.750 & 16 & 21.109 & & \\
\hline Total & 68595.000 & 20 & & & \\
\hline Corrected Total & 966.550 & 19 & & & \\
\hline a. R Squared $=.651$ (Adjusted R Squared $=.585$ ) \\
\hline
\end{tabular}

Berdasarkan tabel di atas memperlihatkan bahwa tidak terdapat pengaruh model CWPT terhadap kreatifitas mahasiswa. Hal ini ditunjukkan dengan nilai sig untuk model yaitu Sig 0.682 $>0.05$. Artinya kreatifitas mahasiswa yang mengalami proses pembelajaran dengan kedua model tersebut sama saja. Sementara itu untuk variabel motivasi, terdapat perbedaan kreatifitas mahasiswa antara mahasiswa yang mendapat perlakuan model CWPT dengan mahasiswa yang mendapat model pembelajaran tutorial konvensional. Model tutorial CWPT baru efektif jika memperhitungkan motivasi mahasiswa. Mahasiswa yang mendapat model CWPT yang memiliki motivasi tinggi akan memperlihatkan kreatifitas yang lebih tinggi dibanding dengan mahasiswa yang memiliki motivasi yang rendah pada model yang sama. Pengaruh motivasi terhadap kreatifitas ditunjukkan dengan nilai Sig $0.000<0.05$.

Ditinjau dari interaksi antara model dan motivasi terhadap kreatifitas mahasiswa ternyata tidak terdapat interaksi antara model dan motivasi terhadap kreativitas mahasiswa karena nilai Sig $0.521>0.05$. Hal ini diperjelas lagi dengan data tabel di bawah ini:

Tabel 7. Mean kreativitas setiap variable penelitian.

\begin{tabular}{|l|c|r|r|r|}
\hline \multicolumn{5}{|c|}{ 1. Model } \\
\hline & & & $95 \%$ Confidence Interval \\
\cline { 3 - 5 } Model & Mean & Std. Error & Lower Bound & Upper Bound \\
\hline CWPT & 58.500 & 1.326 & 55.688 & 61.312 \\
\hline Konvensional & 57.625 & 1.624 & 54.181 & 61.069 \\
\hline
\end{tabular}

\begin{tabular}{|l|c|r|r|r|}
\hline \multicolumn{5}{|c|}{ 2. Motivasi } \\
\hline & & & \multicolumn{1}{|c|}{$95 \%$ Confidence Interval } \\
\cline { 4 - 5 } Motivasi & Mean & Std. Error & Lower Bound & Upper Bound \\
\hline Tinggi & 63.750 & 1.483 & 60.606 & 66.894 \\
\hline Rendah & 52.375 & 1.483 & 49.231 & 55.519 \\
\hline
\end{tabular}




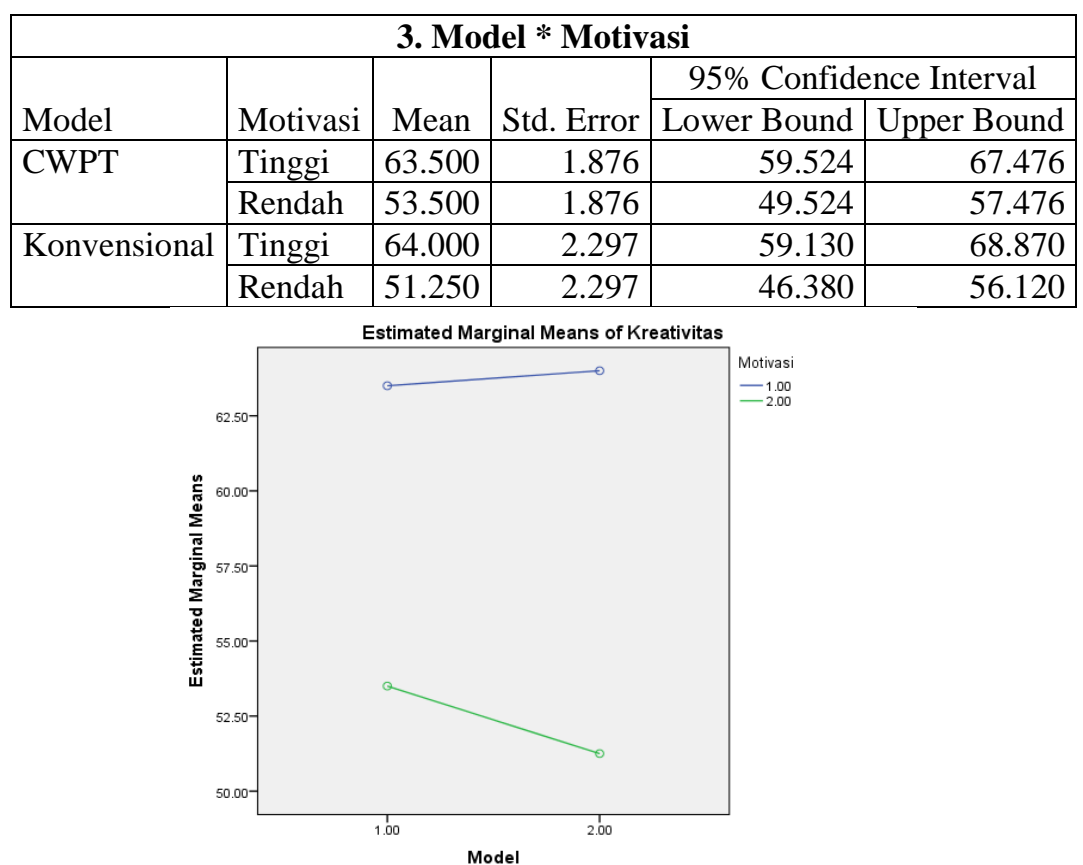

Gambar 1. Grafik yang menunjukkan tidak terjadi interaksi diantara variabel model tutorial dan motivasi terhadap kreativitas mahasiswa dalam pembelajaran ICT

Berdasarkan grafik di atas menunjukkan bahwa tidak terjadi interaksi antara model tutorial dan motivasi dengan kreativitas mahasiswa.

\section{KESIMPULAN}

Kesimpulan penelitian ini adalah :

1. Penerapan Classwide Peer Tutoring (CWPT) berbasis ICT tidak berpengaruh i terhadap kreativitas mahasiswa pendidikan Biologi dalam pembelajaran ICT

2. Motivasi berpengaruh terhadap kreativitas mahasiswa pendidikan Biologi dalam pembelajaran ICT

3. Motivasi tinggi dalam penerapan Classwide Peer Tutoring (CWPT) berbasis ICT berpengaruh terhadap kreativitas mahasiswa pendidikan Biologi dalam pembelajaran ICT

4. Motivasi rendah dalam penerapan Classwide Peer Tutoring (CWPT) berbasis ICT berpengaruh terhadap kreativitas mahasiswa pendidikan Biologi dalam pembelajaran ICT

5. Tidak terdapat interaksi antara penerapan Classwide Peer Tutoring (CWPT) berbasis ICT dan motivasi terhadap kreativitas mahasiswa pendidikan Biologi dalam pembelajaran ICT

\section{DAFTAR RUJUKAN}

Arsyad, A. (2013). Media pembelajaran. Jakarta: Rajawali Pers.

Asrori, M. (2007). Psikologi pembelajaran. Bandung: Wacana Prima.

Bowman, L Perrot (2009). Classwide Peer Tutoring (An Effective Strategy for Students with Emotional and Behavior Disorder). Intervention in School and Clinic, 44(5): 259-267 
Chuang, (2018). A Peer Tutoring Based Concept Mapping to Improving Student Learning Achievment and Attitude, International Journal Online 49(2) 41-46

Clapp, E.P (2019), Participatory creativity: Introducing access and equity to the creative

Classroom. Dynamics Perspectives on Creativity, , vol 4, 27-46

Greenwood,C.R, Mayer,C.A,2001. Classwide Peer Tutoring Learning Management System: Application with Elementary Level English Language Learning, Remedial and Special Education, 22(1),34-47.

Hasibuan, Malayu S.P. (2009). Manajemen Sumber Daya Manusia. Edisi revisi cet.

13 , Jakarta: PT. Bumi Aksara.

Hidayah, E.N, Sajidan., (2012). Penerapan Model Pembelajaran Classwide PeerTutoring disertai Media Cergam untuk Meningkatkan Kualitas Pembelajaran Biologi, Pendidikan Biologi, 4 (2), 98-109.

Mc. Leod, (2018). Promoting Interprofesional and Enhancing Student Experience Through Profesional Peer Teaching. Nurse Education Journal 1(36).

Munawaroh, L. dkk, Penggunaan Jurnal Belajar dalam Pembelajaran Classwide Peer Tutoring terhadap Kemampuan Berpikir Kritis Siswa, Jurnal Pendidikan Biologi Indonesia, 1 (3),263273.

Richardson,C.,Mishra,P (.2018), Learning Environments that Support Creativity: Developing the Scale, Thinking Skills and Creativity, Thinking, vol 27, pp.45-54

Ronald , A Karwowki ., (2018), Educational Consequences of Creativity: Creative Learning Perspective, Creativity, , vol 5, issue 2, 146-154

Susilana, R., Riyana, C. (2011), Media Pembelajaran: hakikat, pengembangan, pemanfaatan dan penilaian. Bandung: CV. Wacana Prima. 